\title{
ASSESSING THE SUCCESS OF SIX SIGMA: AN EMPIRICAL STUDY
}

\begin{tabular}{|l|l|l|}
\hline S. K. Tiwari & R. K. Singh & S. C. Srivastava \\
Department of Production & Department of Production & Department of Production \\
Engineering & Engineering & Engineering \\
Birla Institute of Technology, & Birla Institute of Technology, & Birla Institute of Technology, \\
Mesra, Deoghar Campus & Mesra & Mesra \\
Deoghar, Jharkhand, India. Pin & Ranchi, Jharkhand, India. Pin & Ranchi, Jharkhand, India. Pin \\
Code: 814142 & Code: 835215 & Code: 835215 \\
Email: sanjivtiwari@ bitmesra.ac.in & Email: riteshsingh@bitmesra.ac.in & Email: sharad_scs@yahoo.com \\
\hline
\end{tabular}

\begin{abstract}
In response to the ever increasing demand of customer and prompt changing economic conditions, various industrial engineering and quality management strategies such as ISO 9000, total quality management (TQM), lean manufacturing, manufacturing recourse planning, modular design, reengineering, flexible manufacturing system (FMS), etc., are adopted by the corporations to compete in the current competitive market. However, from the last three decades a new paradigm, known as "Six Sigma", has made its prime impact in the area of manufacturing strategies to solve the problems related to the quality and productivity. In this paper, a case of Indian foundry unit has been presented to explore the effectiveness of six sigma methodology. The DMAIC (Define-Measure-Analyze-ImproveControl) approach of six sigma has been followed here to reduce percentage of defects in green sand casting process. In addition, Taguchi method of parameter design is used to set the optimal process parameters in the 'Improve phase'. Analysis of variance (ANOVA) is then performed to find the optimal parameter levels and to identify the statistical significance and contribution of each factor on the casting defects. Finally, a confirmation test is performed using the optimal parameter setting, which shows that the casting defects can be minimized, effectively. The results show that after successful deployment of six sigma, the percentage of casting defects is reduced by $25.44 \%$.
\end{abstract}

Key Words: green sand casting, six sigma, casting defects, Taguchi technique, design of experiment $(\mathrm{DOE})$, orthogonal array $(\mathrm{OA})$, signal-to-noise ratio, analysis of variance (ANOVA).

\section{INTRODUCTION}

Six sigma is a systematic business management philosophy which concentrates on identifying and eliminating defects, mistakes and variations in a product, process, or service in order to ameliorate the quality at minimum cost. In general, six sigma is a fact-driven, disciplined and statistical approach that is traced to eliminate defects and lead processes to achieve perfection. Being a multifarious system in making business leadership performance more preponderant, six sigma doesn't work based on any single theory/strategy, but it is based on the results driven strategies. The primary goal of six sigma is to ameliorate customer contentment by reducing variation in the process which in turn reduces defects.

Six sigma is a quality amelioration initiative that has been evolved over 25 years of scientific management and perpetual amendment theories. Originally, it was originated by Bill Smith and first utilized by Motorola Corporation in 1986 and targeted a truculent goal of 3.4 defects per million opportunities (DPMO) [1] and had been recognized as a systematic and structured methodology that endeavors to ameliorate operations by eliminating the root causes of defects through focusing on customer needs.

After, Motorola won the Malcom Balridge National Quality Award in 1988 for achieving business excellence through six sigma philosophy, six sigma propagated and the six sigma revolutions were on [2]. GE and other companies like Bank of America, Caterpillar, Honeywell International (previously known as Allied Signal), Raytheon and Merrill Lynch popularized the concept later in the 1990's by its effective application [3]. The six sigma program has been widely accepted to be one of the most prosperous process amendment systems available to businesses. Today, six sigma is well established in virtually every industry and many organizations worldwide have modified six sigma methodology and tools to accommodate their own operations.

Six sigma was initially introduced in manufacturing processes; today, however, it slowly makes its monarchy in cross-functional problem solving issues [4]. This made six sigma one of the most prominent area for both industry and academia. In spite, much of the literatures on six sigma are available only on its definition [4], needs [5], deployment [6], hurdles [7], project selection [8$10]$, critical success factors [11], framework [12- 
13] and organizational infrastructure required for implementation [14]. But only a few studies are reported regarding real life six sigma implementation [15-20].

This paper presents a real case of six sigma implementation in a modern foundry industry. The paper provides set-by-step application of six sigma DMAIC framework to reduce rejection rate in green sand casting process. In addition to that in improve phase, Taguchi Design of Experiment (DOE) is used to set the optimal process parameters in the 'Improve phase'. Analysis of variance (ANOVA) is then performed to find the optimal parameter levels and to identify the statistical significance and contribution of each factor on the casting defects. Finally, a confirmation test is performed using the optimal parameter setting which shows that the casting defects can be minimized effectively.

\section{RESEARCH METHODOLOGY}

There are basically two frameworks namely, DMAIC and DMADV, which are used for the implementation of six sigma improvement strategy as defined by Motorola [3]. In this paper, six sigma DMAIC methodology is applied to identify the root causes for the casting rejections and proposes solutions that can have significant impact on customer, product quality and business from the economic viewpoint.

The first phase is focused on understanding the process under investigation from the point of view of customers, suppliers and operators. The second phase seeks to measure current performance, the third to analyze contributors to poor performance and variation. The fourth phase uses the outputs of the earlier phases to define, test and operationalise improvements and the final phase seeks to ensure that changes are embedded, successful and, where appropriate, transferred to other processes. Table I summarizes the phase, purpose and key outputs [21-22].

\section{INDUSTRIAL CASE}

A case study has been carried out in a leading ferrous casting unit of southern India. All the data required for the research has been collected from the same industry. As an agreement with the company its name should be made confidential and thus for the research purpose it has been named as XYZ company Ltd. XYZ has since been a significant and diligent participant in the ferrous casting industry, producing superior quality castings for many industries. Today, it is one of India's largest suppliers of the finest ductile iron, grey iron and mild steel castings ranging from 0.5 $\mathrm{Kg}$ to $260 \mathrm{Kg}$ in weight, having turnover of about 3000 tons per month. The company is catering to the needs of commercial vehicle industry, Tractor industry, car manufacturers and it also full fills the casting needs of many other industries.

Despite of adopting these world class standards and continuously striving for the improvements, the company is unable to fulfill the increased demand in the last ten years due to globalization and boom in automobile sector. After continual effort and brainstorming with the production data, it can be concluded that the main culprit of this problem is reworks/rejections which basically due to defects in the products and unreliable process. So, the top management of the company decided to implement the world's prominent methodology namely six sigma DMAIC methodology in order to reduce the reworks/rejections thus making the process so robust that the present demand can be fulfilled with the existing resources.

\section{SIX SIGMA DEPLOYMENT}

\section{A. Define Phase}

The aim of this phase is to define the scope and goal of the improvement project in terms of customer requirements and to develop a process that delivers these requirements. In this concern, a project charter is made with all the necessary details of the project (Table II). This helps the team members in understanding the project objective, duration, resources, roles and responsibilities of team members, project scope and boundaries, expected results from the project, etc., [23]. Since there is a cross-functional team for executing this project, thus the team decided to perform SIPOC (Supplier-Input-Process-Output-Customer) analysis to have a better understanding of the process. SIPOC diagram is presented in Fig.1.

TABLE I. SUMMARY OF DMAIC

\begin{tabular}{|c|l|}
\hline Phases & \multicolumn{1}{|c|}{ Purpose } \\
\hline Define & Define the project's purpose and scope \\
\hline Measure & Gather information regarding existing process conditions to provide a baseline \\
\hline
\end{tabular}




\begin{tabular}{|c|l|}
\hline & $\begin{array}{l}\text { assessment of current performance levels and narrow the scope of inquiry to the } \\
\text { most important problems }\end{array}$ \\
\hline Analyze & Identify the root causes of the problems that were clarified in the Measure Stage \\
\hline Improve & $\begin{array}{l}\text { Develop, implement, and evaluate solutions intended to eliminate the root causes } \\
\text { of problems identified in the analyze stage }\end{array}$ \\
\hline Control & $\begin{array}{l}\text { Ensure that problems remain fixed and that the new methods can be improved } \\
\text { over time }\end{array}$ \\
\hline
\end{tabular}

\section{TABLE II. PROJECT CHARTER}

\begin{tabular}{|l|l|}
\hline \multicolumn{2}{|c|}{ Project Charter } \\
\hline Project title & To reduce rejection rate in green sand casting process. \\
\hline Background/Reason & $\begin{array}{l}\text { Currently, the rejection rate is as high as 10.64\% approximately, which costs approximately 2 } \\
\text { crore per month. In addition, various other losses such as raw material, machine hour, man } \\
\text { hour, etc., are associated with the rejection of the casting. }\end{array}$ \\
\hline Critical to quality & $\begin{array}{l}\text { Percentage of casting rejections (approximately 89.67\% of total) due to core making unit, } \\
\text { mould making unit and melting unit. }\end{array}$ \\
\hline Project scope & Green sand casting process. \\
\hline Project leader & Manufacturing head. \\
\hline Team members & $\begin{array}{l}\text { Production manager, manager from quality assurance department, shop floor operators, } \\
\text { foundry technicians, author. }\end{array}$ \\
\hline Expected benefits & Saving of approximately 2 crore per month. \\
\hline Schedule & $\begin{array}{l}\text { Define: 2 weeks } \\
\text { Measure: 3 weeks } \\
\text { Analyze: 3 weeks } \\
\text { Improve: 2 weeks } \\
\text { Control: } 4 \text { weeks }\end{array}$ \\
\hline
\end{tabular}

Fig. 1. SIPOC Diagram

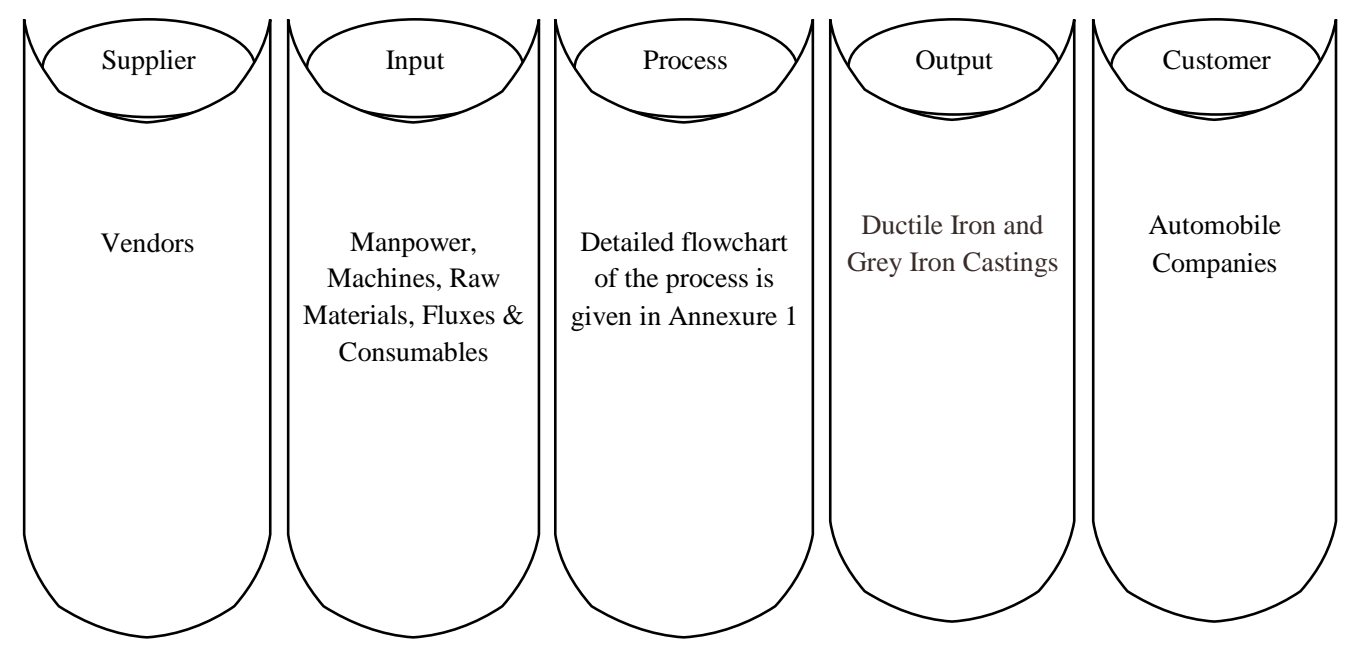

is constructed to represent the percentage of defective products coming from each unit and is

\section{B. Measure Phase}

The objective of the measure phase is to understand and establish the baseline performance of the process in terms of process capability or sigma rating. For this the team has collected the defect data of five months (Jan, 14 to May, 14) of various shops/units and the data for the same is depicted in Table III. It can be concluded from Table III that maximum number of defects are coming from core making unit (11.18\%), mould making unit $(60.56 \%)$ and melting unit $(17.93 \%)$ in the form of defective casting/product. These three units contribute $89.67 \%$ of the total defects. A bar graph shown in Fig. 2.

The defects occurring in the above three units are significantly affecting the production and performance of the company. A meeting of all the team members are called to analyze the various defects occurring in these units and to discuss the remedial action for streamlining the whole process. Fig. 3 shows the various casting defects and their significance to make the casting defectives. It can be concluded from the Fig. 3 that scab, blow holes, bad core, sand drop, sand inclusion, shrinkage, core shift and cold shut are erupting as the prime 


\section{ELK}

\section{Asia Pacific Journals}

reasons for $80 \%$ of the defective castings (i.e., vital few).

Next, the team measured the overall sigma value of the casting process in order to have a clear picture of the current state of the production. The calculation of sigma level is based on the number of defects per million opportunities (DPMO). In order to calculate the DPMO, three distinct pieces of information are required:

a) The number of unit produced.

b) The number of defect opportunities per unit.

c) The number of defects.

The actual formula is:
ELK Asia Pacific Journals - Special Issue

ISBN: 978-81-930411-4-7

DPMO $=$

(Number of defects $\times 1,000,000)$

(cNumber of defects opportunities funit) xNumber of units)

In the present study, the number of unit produced $=$ 119967, the number of defects $=12771$ (refer to Table III), and the number of defect opportunities per unit $=14$ (refer to Fig. 3).

Therefore, $D P M O=\frac{(12771 \times 1,000,000)}{(14 \times 119967)}=7,603.87$

Referring to six sigma table [24], the sigma value for 7,603.87 DPMO is 3.9.

TABLE III. DEFECT DATA FROM VARIOUS UNITS

\begin{tabular}{|l|l|l|l|l|l|l|}
\hline \multirow{2}{*}{ Processes } & \multicolumn{7}{|c|}{ Number of defects } \\
\cline { 2 - 7 } & Jan,14 & Feb,14 & March,14 & April,14 & May,14 & Sum \\
\hline Core making & 285 & 326 & 227 & 310 & 280 & 1428 \\
\hline Mould making & 1684 & 1388 & 1535 & 1480 & 1648 & 7735 \\
\hline Melting & 462 & 405 & 448 & 478 & 498 & 2291 \\
\hline Shot blasting I & 40 & 38 & 56 & 48 & 52 & 234 \\
\hline Fettling / grinding & 151 & 190 & 210 & 181 & 226 & 958 \\
\hline Shot blasting II & 20 & 15 & 18 & 23 & 16 & 92 \\
\hline Painting & 5 & 4 & 7 & 9 & 8 & 33 \\
\hline Total defectives & 2647 & 2366 & 2501 & 2529 & 2728 & 12771 \\
\hline Total units produced & 23962 & 22811 & 23780 & 24520 & 24894 & 119967 \\
\hline \% Of defects & 11.05 & 10.37 & 10.52 & 10.31 & 10.99 & 10.64 \\
\hline
\end{tabular}

Fig. 2. Percentage of total defect observed in various units

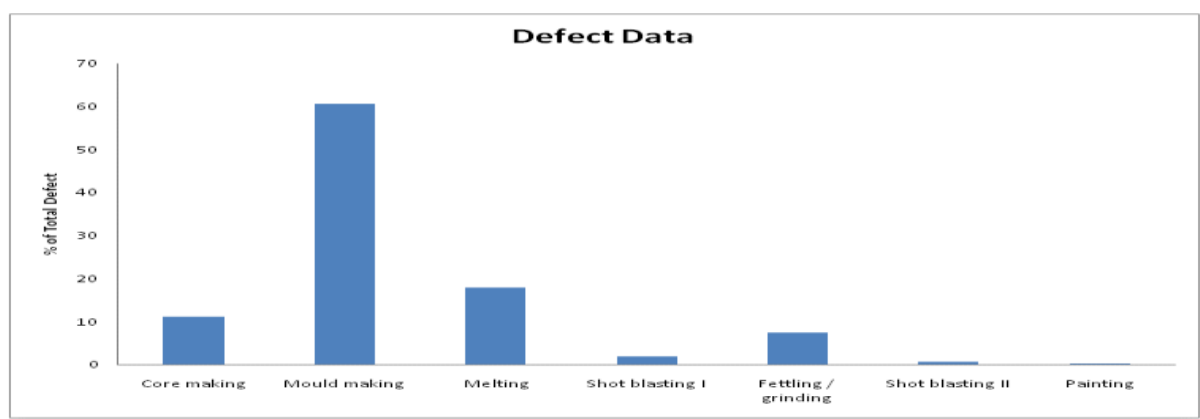

Fig. 3. Pareto chart for the analysis of vital few 


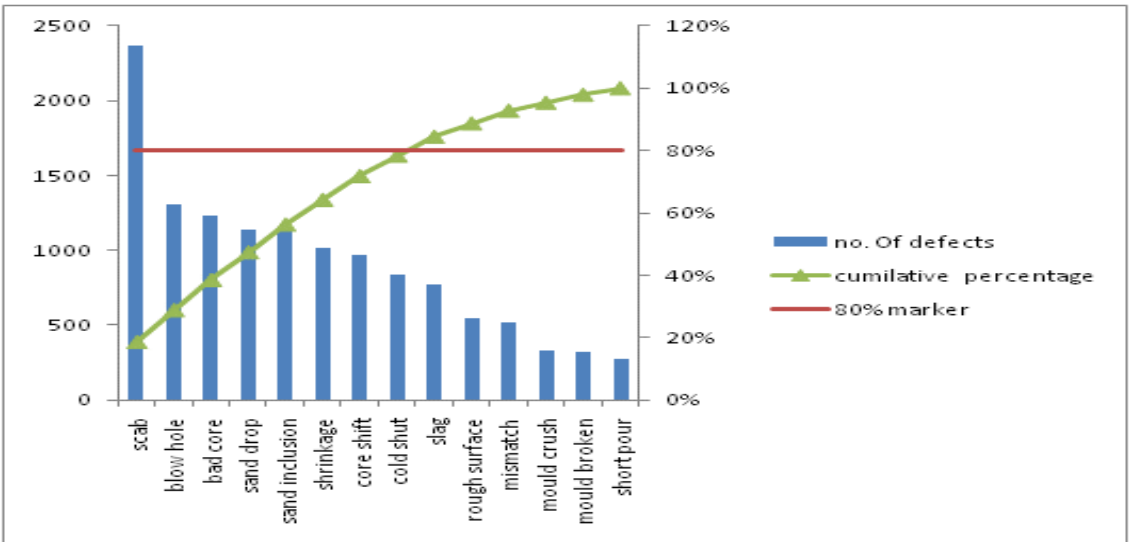

\section{Analyze Phase}

In this phase the collected data is verified, analyzed and prioritized in order to explore the possible root causes and their relationship to output. For this purpose the team decided to first construct a control chart in order to check the current condition of the process, shown in figure 4 . At this point, it is essential to identify the possible causes of casting defects and thus a cause and effect diagram is constructed in order to identify, sort, and display the possible causes of the problem shown in Fig. 5.

From the cause and effect diagram, it may be concluded that the most significant factors that affect casting defects are green compression strength, permeability, pouring temperature, mould hardness and moisture content. Table IV shows the selected process parameters, along with their ranges.

Fig. 4. Control chart ( $\mathrm{X}$ bar and $\mathrm{S}$ chart) before improvement

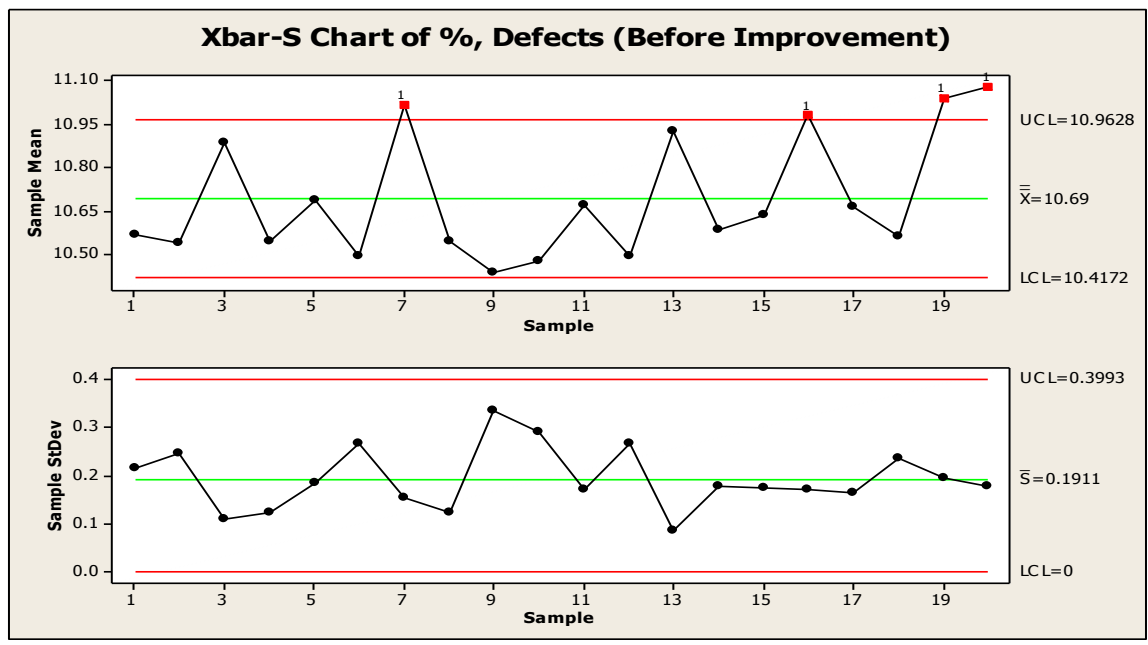

Fig. 5. Cause and effect diagram 


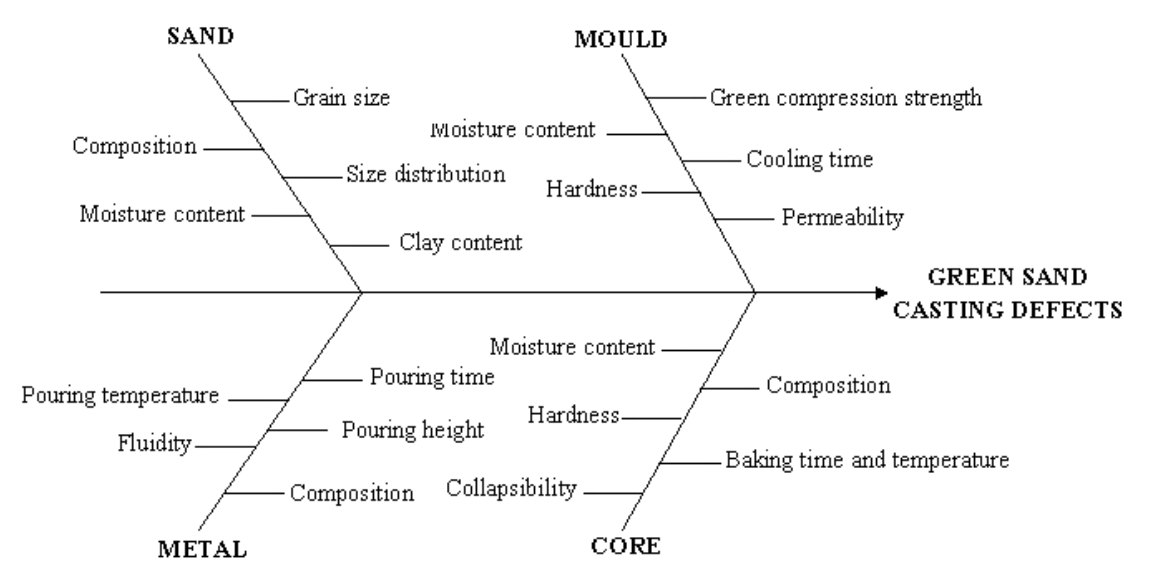

TABLE IV. PROCESS CONTROL FACTORS AND THEIR LEVELS

\begin{tabular}{|c|c|c|c|c|c|}
\hline $\begin{array}{c}\text { Control factors } \\
\text { designation }\end{array}$ & Control factors & Range & Level 1 & Level 2 & Level 3 \\
\hline A & Green compression strength $\left(\mathrm{g} / \mathrm{cm}^{2}\right)$ & $1500-1800$ & 1500 & 1800 & -- \\
\hline B & Permeability (No.) & $100-160$ & 100 & 130 & 160 \\
\hline C & Pouring temperature $\left({ }^{\circ} \mathrm{C}\right)$ & $1380-1450$ & 1380 & 1420 & 1450 \\
\hline D & Mold hardness (No.) & $80-100$ & 80 & 90 & 100 \\
\hline E & Moisture content (\%) & $2.8-3.4$ & 2.8 & 3.1 & 3.4 \\
\hline
\end{tabular}

\section{Improve Phase}

The objective of improve phase is to empirically explore the solutions to eliminate these causes. In this research, Taguchi's DOE has been used for the design and modeling of the experiment.

Experimental Design: In this study, there is no particular reason to examine the specific interactions of the control elements. Therefore, the experiment is designed, based on one two level control factor (Green compression strength) and other control factors (Permeability, Pouring temperature, mold hardness, and Moisture content) having three levels. Thus, L18 orthogonal array is selected with 18 experimental runs and eight columns.

Once the parameters were assigned to the experimental array, the experiments were conducted thrice for the same set of parameters using a single-repetition randomization technique [25]. The casting defects that occur in each trial condition were measured. The average of the casting defects was found for each trial condition as shown in Table V.

Experimental Analysis: All the analysis is carried out by using MINITAB ${ }^{\circledR} 15$.Statistical analysis like $\mathrm{S} / \mathrm{N}$ ratio analysis and analysis of variance
(ANOVA) were performed at a significance level of 0.05 (i.e. $\alpha=0.05$ ) or at the 95 percent confidence level. In this study, casting defect is selected as quality characteristic and casting defect is "smaller-the-better" type of quality characteristic [26-28]. Here the objective function to be minimized is:

Lower is better: $\eta_{\mathrm{i}}=-10 \log _{10}\left(\frac{1}{n} \sum_{i=1}^{n} y_{i}^{2}\right)$

where, $\eta_{\mathrm{i}}=S / N$ Ratio, the ratio used for measuring sensitivity to noise factors,

$\mathrm{n}=$ number of experiments in orthogonal array, and $y_{i}=i^{\text {th }}$ value measured.

For analyzing the results obtained from the experiments, the $\mathrm{S} / \mathrm{N}$ ratio is calculated (Table $\mathrm{V}$ ) using Eq. (2). For example, for the experiment no. 1 , the $\mathrm{S} / \mathrm{N}$ ratio is:

$$
\begin{aligned}
S / N \text { Ratio } & =-10 \log _{10}\left(\frac{\left(11.1^{2}+10.91^{2}+11.47^{2}\right)}{3}\right) \\
& =-20.96 \mathrm{~dB} .
\end{aligned}
$$

The response of $\mathrm{S} / \mathrm{N}$ ratios and means for each point is calculated and the results are summarized in Table VI \& Table VII. The effects $\mathrm{S} / \mathrm{N}$ ratios and 
means of the individual process parameters on the casting defects are shown in Fig. 6 and Fig. 7. From Fig. 6, it can be concluded that $\mathrm{S} / \mathrm{N}$ ratio at the second level of green compression strength $\left(A_{2}\right)$, second level of permeability $\left(B_{2}\right)$, third level of pouring temperature $\left(\mathrm{C}_{3}\right)$, second level of mold hardness $\left(D_{2}\right)$, and first level of moisture content $\left(E_{1}\right)$ is maximized. It signifies that the defect level at these levels should be minimized, which can be replicated in Fig. 7. Thus, the percentages of casting defects are minimal at $\mathrm{A}_{2} \mathrm{~B}_{2} \mathrm{C}_{3} \mathrm{D}_{2} \mathrm{E}_{1}$.

After that, ANOVA test is performed to look into the most significant casting parameter that potentially affects the quality characteristics. This can be achieved by dividing the total variability of the $\mathrm{S} / \mathrm{N}$ ratios, which is measured by the sum of squared deviations from the total mean of the $\mathrm{S} / \mathrm{N}$ ratio, in contributions by each casting process parameter and the error. The ANOVA results are shown in Table VIII. In ANOVA, the ratio between the variance of the process parameter and the error variance is called Fisher's ratio and it is used to determine whether or not the parameter has a significant effect on the quality characteristic. This procedure is carried out by comparing the F-test value of the parameter with the standard $\mathrm{F}$ table value (F0.05) at the 5 percent significance level. If the F-test value is greater than F0.05, the process parameter is considered to be significant. From Table VIII, it can be concluded that parameters A, $\mathrm{B}, \mathrm{C}$ are statistically significant and parameters D and $\mathrm{E}$ are statistically insignificant and thus can be removed from the further study.
Determination of optimal factor levels: The best values of green sand casting process parameters for the minimum defects are identified from Fig. 6 and Fig. 7. Based on the main effects plot for $\mathrm{S} / \mathrm{N}$ ratios and means, the optimal green sand casting process parameters, within the range of testing values, are chosen as green compression strength at level 2 $\left(1800 \mathrm{~g} / \mathrm{cm}^{2}\right)$, Permeability at level 2 (130), Pouring temperature at level $3\left(1450{ }^{\circ} \mathrm{C}\right)$, mold hardness at level 2 (90), and Moisture content at level 1 (2.8\%), i.e., $\mathrm{A}_{2} \mathrm{~B}_{2} \mathrm{C}_{3} \mathrm{D}_{2} \mathrm{E}_{1}$.

Confirmation Test: After calculating the optimal level of the sand casting process parameters, the improvement of the quality characteristics using the optimal level of the sand casting parameters are predicted and verified. The estimated $\mathrm{S} / \mathrm{N}$ ratio, $\eta_{\text {opt }}$, using the optimal level of the casting parameters is calculated as [29]

$$
\eta_{\text {opt }}=\hat{\eta}+\sum_{j=1}^{q}\left(\eta_{j}-\hat{\eta}\right)
$$

where, $\hat{\eta}$ is total average $\mathrm{S} / \mathrm{N}$ ratio of all the experimental values, $\eta_{j}$ is the mean $\mathrm{S} / \mathrm{N}$ ratio at the optimal level, and $q$ is the number of casting parameters that significantly influence the quality characteristics.

Table IX shows the results of confirmation test which is performed by using the optimal setting of green sand casting parameters and levels. From the Table IX, it can be noted that the percentage of casting defects at the optimal levels is 3.36, a decrease of $25.44 \%$, against the initial process parameters setting.

TABLE V. EXPERIMENTAL ASSIGNMENTS, RESULTS, AND S/N RATIOS

\begin{tabular}{|c|c|c|c|c|c|c|c|c|c|c|}
\hline \multirow{2}{*}{$\begin{array}{c}\text { Experiment } \\
\text { No. }\end{array}$} & \multicolumn{4}{|c|}{ Process parameters } & \multicolumn{5}{c|}{ Percentage defects in experiments } \\
\cline { 2 - 12 } & $\boldsymbol{A}$ & $\boldsymbol{B}$ & $\boldsymbol{C}$ & $\boldsymbol{D}$ & $\boldsymbol{E}$ & Trail 1 & Trail 2 & Trail 3 & Average & S/N ratio $(\boldsymbol{d B})$ \\
\hline 1 & 1500 & 100 & 1380 & 80 & 2.8 & 11.10 & 10.91 & 11.47 & 11.16 & -20.96 \\
\hline 2 & 1500 & 100 & 1420 & 90 & 3.1 & 10.12 & 10.48 & 10.24 & 10.28 & -20.24 \\
\hline 3 & 1500 & 100 & 1450 & 100 & 3.4 & 9.28 & 9.56 & 9.77 & 9.54 & -19.59 \\
\hline 4 & 1500 & 130 & 1380 & 80 & 3.1 & 7.24 & 7.25 & 6.87 & 7.12 & -17.05 \\
\hline 5 & 1500 & 130 & 1420 & 90 & 3.4 & 6.65 & 6.16 & 6.81 & 6.54 & -16.32 \\
\hline 6 & 1500 & 130 & 1450 & 100 & 2.8 & 6.13 & 6.18 & 7.20 & 6.50 & -16.29 \\
\hline 7 & 1500 & 160 & 1380 & 90 & 2.8 & 7.73 & 7.36 & 7.44 & 7.51 & -17.51 \\
\hline 8 & 1500 & 160 & 1420 & 100 & 3.1 & 8.25 & 8.49 & 8.92 & 8.55 & -18.65 \\
\hline 9 & 1500 & 160 & 1450 & 80 & 3.4 & 6.98 & 6.56 & 6.74 & 6.76 & -16.6 \\
\hline 10 & 1800 & 100 & 1380 & 100 & 3.4 & 10.87 & 10.76 & 11.11 & 10.91 & -20.76 \\
\hline 11 & 1800 & 100 & 1420 & 80 & 2.8 & 8.63 & 9.87 & 9.04 & 9.18 & -19.27 \\
\hline
\end{tabular}




\begin{tabular}{|c|c|c|c|c|c|c|c|c|c|c|}
\hline 12 & 1800 & 100 & 1450 & 90 & 3.1 & 7.77 & 7.90 & 8.06 & 7.91 & -17.96 \\
\hline 13 & 1800 & 130 & 1380 & 90 & 3.4 & 5.26 & 5.30 & 5.53 & 5.36 & -14.59 \\
\hline 14 & 1800 & 130 & 1420 & 100 & 2.8 & 5.16 & 5.10 & 5.20 & 5.15 & -14.24 \\
\hline 15 & 1800 & 130 & 1450 & 80 & 3.1 & 4.51 & 4.46 & 4.57 & 4.51 & -13.09 \\
\hline 16 & 1800 & 160 & 1380 & 100 & 3.1 & 5.74 & 5.59 & 5.46 & 5.60 & -14.96 \\
\hline 17 & 1800 & 160 & 1420 & 80 & 3.4 & 5.72 & 4.46 & 4.67 & 4.95 & -13.95 \\
\hline 18 & 1800 & 160 & 1450 & 90 & 2.8 & 4.16 & 3.82 & 4.68 & 4.22 & -12.54 \\
\hline
\end{tabular}

TABLE VI. RESPONSE TABLE FOR S/N RATIOS

\begin{tabular}{|c|c|c|c|c|c|}
\hline Level & A & B & C & D & E \\
\hline 1 & -18.13 & -19.80 & -17.64 & -16.82 & -16.80 \\
\hline 2 & -15.71 & -15.26 & -17.11 & -16.53 & -16.99 \\
\hline 3 & & -15.70 & -16.01 & -17.41 & -16.97 \\
\hline Delta & 2.43 & 4.53 & 1.63 & 0.89 & 0.19 \\
\hline Rank & 2 & 1 & 3 & 4 & 5 \\
\hline
\end{tabular}

TABLE VII. RESPONSE TABLE FOR MEANS

\begin{tabular}{|c|c|c|c|c|c|}
\hline Level & A & B & C & D & E \\
\hline 1 & 8.22 & 9.83 & 7.94 & 7.28 & 7.29 \\
\hline 2 & 6.42 & 5.87 & 7.44 & 6.97 & 7.33 \\
\hline 3 & & 6.27 & 6.57 & 7.71 & 7.34 \\
\hline Delta & 1.80 & 3.96 & 1.37 & 0.74 & 0.05 \\
\hline Rank & 2 & 1 & 3 & 4 & 5 \\
\hline
\end{tabular}

Fig. 6. Main effects plot for $\mathrm{S} / \mathrm{N}$ ratios

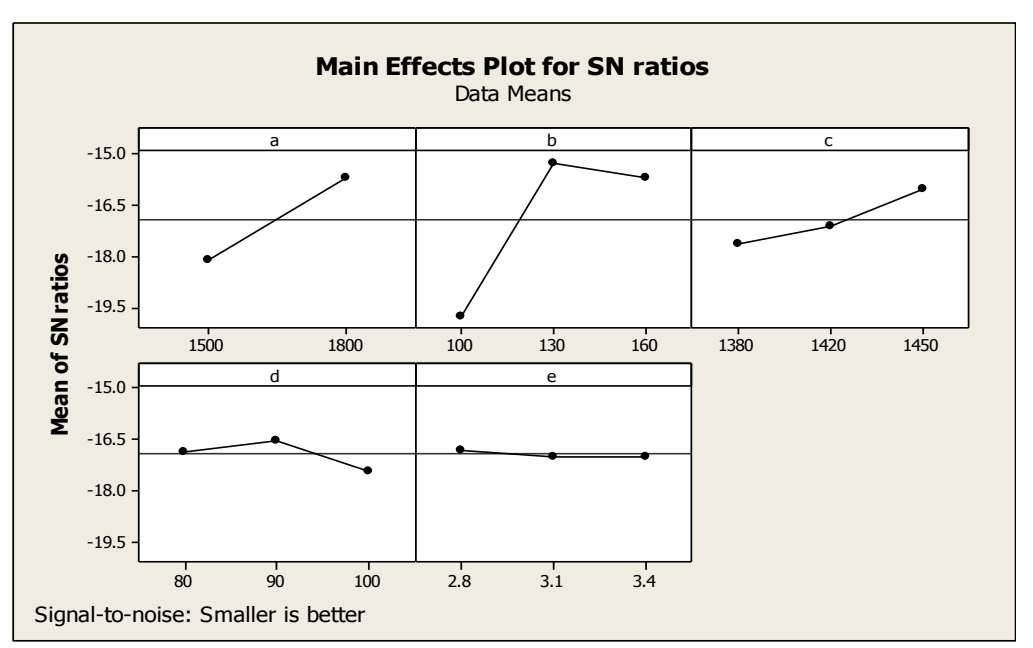

Fig. 7. Main effects plot for means 


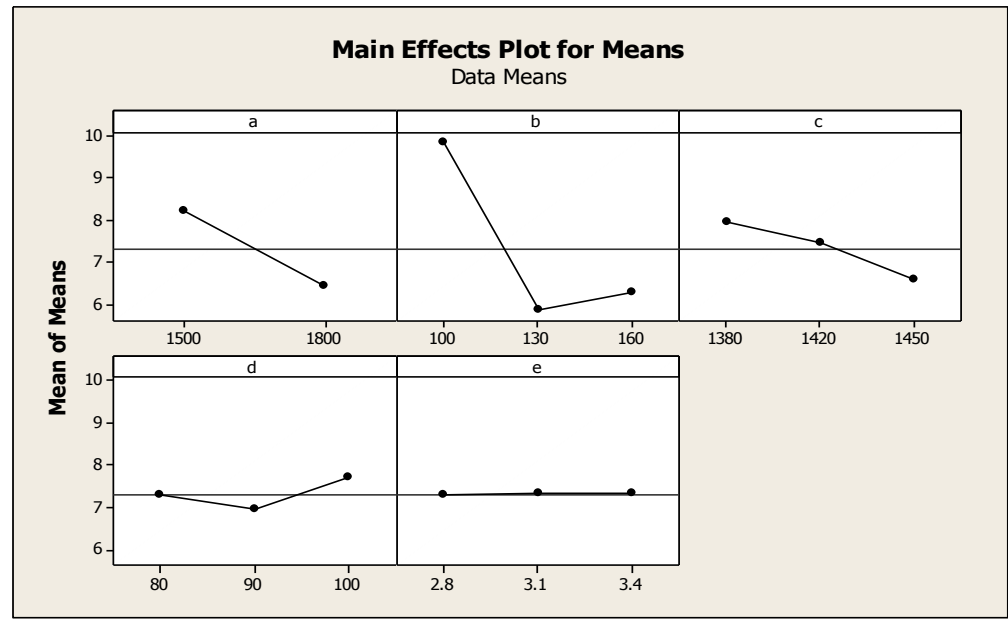

TABLE VIII. ANOVA SUMMARY

\begin{tabular}{|c|c|c|c|c|c|c|}
\hline Source & $\begin{array}{c}\text { Degree of } \\
\text { freedom }\end{array}$ & $\begin{array}{c}\text { Sum of } \\
\text { square }\end{array}$ & Variance & F & $\begin{array}{c}\text { Significance } \\
\text { of F }\end{array}$ & $\begin{array}{c}\text { Percent } \\
\text { contribution }\end{array}$ \\
\hline A & 1 & 26.518 & 26.518 & 31.28 & 0.001 & 21.54 \\
\hline B & 2 & 75.030 & 37.515 & 44.32 & 0.000 & 61.53 \\
\hline C & 2 & 8.269 & 4.1345 & 4.88 & 0.041 & 5.52 \\
\hline D & 2 & 2.451 & 1.2255 & 1.45 & 0.291 & \\
\hline E & 2 & 0.130 & 0.065 & 0.08 & 0.927 & \\
\hline Error & 8 & 6.782 & 0.8477 & & & 11.41 \\
\hline Total & 17 & 119.179 & & & & 100.00 \\
\hline
\end{tabular}

TABLE IX. RESULTS OF CONFIRMATION TEST

\begin{tabular}{|c|c|c|}
\hline \multirow{2}{*}{ Level } & Percentage defects & S/N ratios (dB) \\
\cline { 2 - 3 } & $\boldsymbol{A}_{\boldsymbol{2}} \boldsymbol{B}_{2} \boldsymbol{C}_{\boldsymbol{3}} \boldsymbol{D}_{\mathbf{2}} \boldsymbol{E}_{\boldsymbol{1}}$ & $\boldsymbol{A}_{\boldsymbol{2}} \boldsymbol{B}_{\boldsymbol{2}} \boldsymbol{C}_{\boldsymbol{3}} \boldsymbol{D}_{\boldsymbol{2}} \boldsymbol{E}_{\boldsymbol{1}}$ \\
\hline Initial parameters setting & 4.51 & -13.09 \\
\hline Optimal parameters setting & 3.36 & -9.76 \\
\hline Improvement (\%) & 25.44 & 25.44 \\
\hline
\end{tabular}

\section{E. Control Phase}

The objective of control phase is to ascertain that the current process must be in control after the successful implementation of improvement solutions that has been determined in the improve phase. The team should timely monitor the process in order to ensure sustainability of the achieved results. If any special causes are determined, corrective actions should be taken before nonconformities are produced. For this the team decided to construct the control chart of the existing process (i.e., after improvement) in order to determine the current situation of the process as depicted in fig. 8. The interpretation of the control chart shows that the current process is under control and also the variation is reduced. In addition, the current sigma value is calculated which is found to be approximately 4.1 .

The main purpose of six sigma is not only making process improved but also having the optimum results sustained in long run. Hence, the standardization of the process is required. For that, proper documentation of the process and appropriate training of the people associated with the process should be conducted so that they can able to manage the process effectively.

\section{RESULTS AND DISCUSSION}

In this study six sigma DAMIC methodology is used to reduce rejection rate of the green sand 
casting. The results obtained after the improvement are discussed below:

1) The optimum levels of the parameters at which defect level will be minimal are: green compression strength at level 2 $\left(1800 \mathrm{~g} / \mathrm{cm}^{2}\right)$, permeability at level 2 (130), pouring temperature at level 3 $\left(1450{ }^{\circ} \mathrm{C}\right)$, mould hardness at level 2 (90), and moisture content at level 1 (2.8\%), i.e., $\mathrm{A}_{2} \mathrm{~B}_{2} \mathrm{C}_{3} \mathrm{D}_{2} \mathrm{E}_{1}$.

2) From ANOVA results, parameters green compression strength, permeability, and pouring temperature are significant and parameters mould hardness, and moisture content is insignificant.

3) Percentage contribution: Permeability (61.53 per cent) has the most dominant effect on total variation and it is followed by green compression strength (21.54 per cent) and pouring temperature (5.52 percent).

4) It can be concluded that the sigma value before improvement is 3.9, while it becomes 4.1 after improvement. Similarly, percentage of casting defects is reduced by $25.44 \%$.

Fig. 8. Control chart (X bar and S chart) after improvement

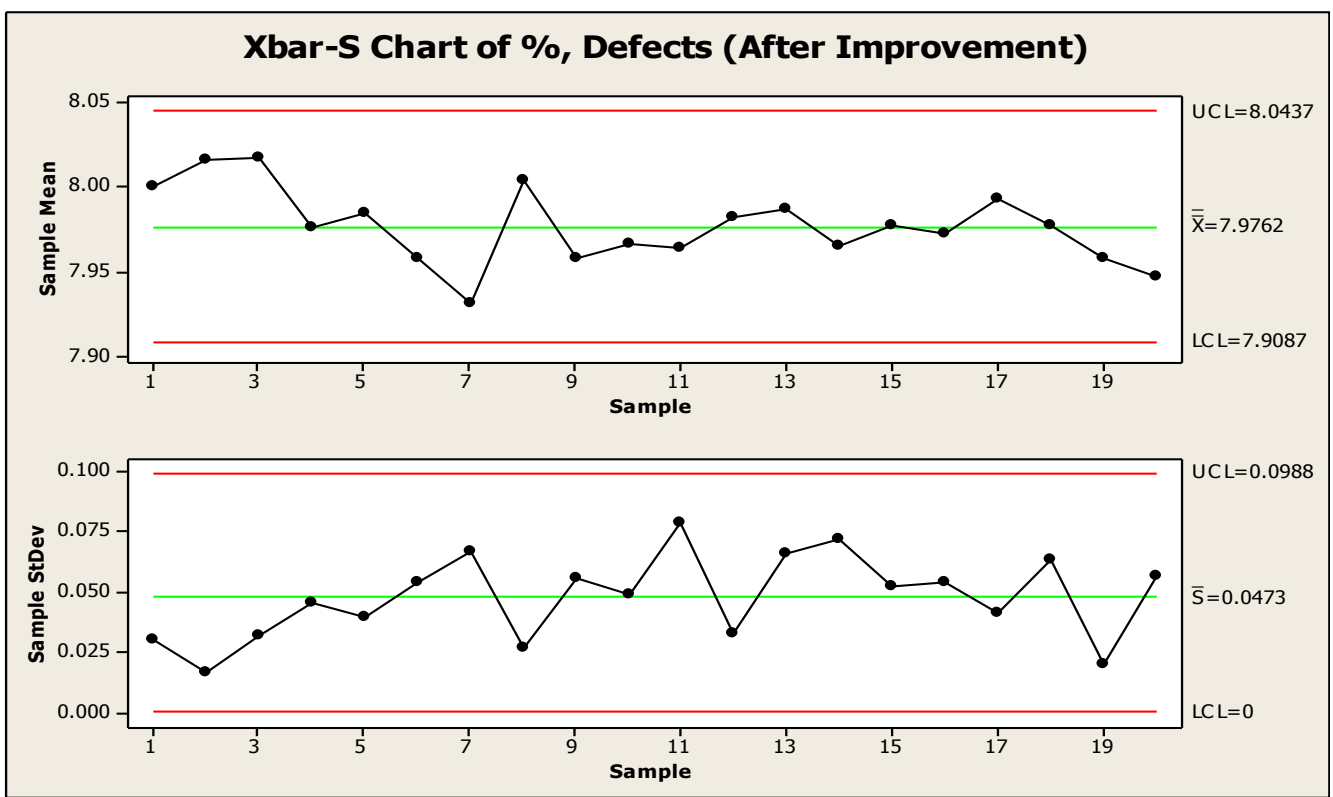

\section{CONCLUSION AND FUTURE WORK}

Due to global competitiveness manufacturing industries are facing a tough challenge to produce high quality and customized products at low cost to meet the uprising market demand. Six sigma was evolved as one of the powerful methodology in order to tackle these situations. Six sigma is a project-driven management approach that is pertinent to all the arenas starting from manufacturing to service industries. It enhances the process efficiency by identifying and eliminating the defects.

This paper presents the step-by-step application of the Six Sigma DMAIC methodology for reducing the rejection rate of casting in an Indian foundry unit. The research findings show that the rejection rate of casting has been reduced to $3.36 \%$ from $4.51 \%$. As a result, the cost associated with rejection, repair, scrap and re-inspection can be reduced and the company is realized an annual saving of about US\$ 0.45 million. In addition, for the complete organizational involvement, timely training of the employees and updating regarding the new technologies are to be planned. Also, to encourage the people for participating in the Six Sigma improvement initiative, the management should declare an incentive schemes for the successful teams. 


\section{Acknowledgement}

The authors would like to thank the reviewers for their constructive suggestions and recommendations.

\section{References}

[1] R. Andersson, H. Eriksson, and H. Torstensson, "Similarities and differences between TQM, six sigma and lean," The TQM Magazine, vol. 18, no. 3, 2006, pp. 282-96, 2006.

[2] P. Thomas, The six sigma revolution, Quality America Inc., 2008.

[3] R. Snee, and R. Hoerl, Leading six sigma - a step by step guide based on experience with GE and other six sigma companies, Prentice-Hall: New Jersey, 2003.

[4] F.W. Breyfogle, Implementing Six Sigma: Smarter Solutions Using Statistical Methods, Wiley: New York, 2003.

[5] P. Pande, R. Neuman, and R. Cavanagh, The six sigma way: how GE, Motorola and other top companies are honing their performance, McGrawHill: New York, 2000.

[6] P.A. Keller, Six Sigma Deployment, Quality Publishing House: Arizona, 2001.

[7] E.V. Gijo, and T.S. Rao, "Six sigma implementation-hurdles and more hurdles," Total Quality Management \& Business Excellence, vol. 16, no. 6, pp. 721-725, 2005.

[8] P. Pande, R. Neuman, and R. Cavanagh, The six sigma way team field book: an implementation guide for process improvement teams, Tata McGraw-Hill: New Delhi, 2003.

[9] S. Boran, H.R. Yazgan, and K. Goztepe, "A fuzzy ANP-based approach for prioritizing projects: a six sigma case study," Int. J. Six Sigma and Competitive Advantage, vol. 6, no. 3, pp.133-155, 2011.

S.K. Tiwari, R.K. Singh, and S.C. Srivastava, "Six sigma project selection using extent fuzzy AHP: an empirical study," Int. J. Research in Industrial Engineering, vol. 2, no. 2, pp. 50-63, 2013.

[11] D.A. Desai, J. Antony, and M.B. Patel, "An assessment of the critical success factors for six sigma implementation in Indian industries," International Journal of Productivity and Performance Management, vol. 61, no. 4, pp. 5 - 5, 2012.
G. Celano, S. Fichera, A. Costa, and G. Tringali, "Linking six sigma to simulation: a new roadmap to improve the quality of patient care," International Journal of Health Care Quality Assurance, vol. 25, no. 4, pp. 2-2, 2012.

[13] C. Heavey, and E. Murphy, "Integrating the Balanced Scorecard with six sigma," The TQM Journal, vol. 24, no. 2, pp. 108 - 122, 2012.

[14] S. Taghizadegan, Essentials of lean six sigma, Elsevier: New Delhi, 2006.

[15] R.G.P. Prasada, and R.V. Venugopal, "Process improvement using six sigma - a case study in small scale industry," International Journal of Six Sigma and Competitive Advantage, vol. 6, nos. 1/2, pp. 111, 2010.

[16] E.V. Gijo, and J. Scaria, "Reducing rejection and rework by application of six sigma methodology in manufacturing process," Int. J. Six Sigma and Competitive Advantage, vol. 6, nos. 1/2, pp.77-90, 2010.

[17] E.V. Gijo, J. Scaria, and J. Antony, "Application of six sigma methodology to reduce defects of a grinding process," Quality and Reliability Engineering International, vol. 27, pp. 1221-1234, 2011.

[18] P.C. Gholap, and T.N. Desai, "Reduction of rework the six sigma way: case study of an Indian small scale industry," Int. J. Six Sigma and Competitive Advantage, vol. 7, no. 1, pp.92-116, 2012.

[19] A. Kumaravadivel, and U. Natarajan, "Application of six sigma DMAIC methodology to sand-casting process with response surface methodology," International Journal of Advance Manufacturing \& Technology, vol. 69, pp. 1403-1420, 2013.

[20] B.J. Singh, and D. Khanduja, "Ambience of six sigma in Indian foundries - an empirical investigation," Int. J. Six Sigma and Competitive Advantage, vol. 7, no. 1, pp. 12-40, 2012.

[21] G. Knowles, L. Whicker, J.H. Femat, and F.D.C. Canales, "A conceptual model for the application of six sigma methodologies to supply chain improvement," International Journal of Logistics Research and Applications, vol. 8, no. 1, pp. 51-65, 2005.

[22] A.Y.T. Szeto, and A.H.C. Tsang, "Antecedents to successful implementation of Six Sigma," Int. J. Six Sigma and Competitive Advantage, Vol. 1, No. 3, pp. 307-322, 2005. 


\section{ELK}

\section{Asia Pacific Journals}

[23] J. Antony, E.V. Gijo, and S.J. Childe, "Case study in six sigma methodology: manufacturing quality improvement and guidance for managers," Production Planning and Control, iFirst, pp. 1-17, 2011.

[24] http://home.xtra.co.nz/hosts/smtconz/Quality/Simple $\% 20$ Six \%20Sigma\%20Calculator.xls

[25] P.J. Ross, Taguchi Technique for Quality Engineering, $2^{\text {nd }}$ Edition, Tata McGraw-Hill, 1988.

[26] T.P. Bagchi, Taguchi methods explained, practical steps to robust design, Prentice Hall of India Pvt. Ltd., New Delhi, India, 1993.

[27] P.B. Barua, P. Kumar, and J.L. Gaindhar, "Optimization of mechanical properties of Vprocess casting by Taguchi method," Indian Foundry Journal, pp. 17-25, 1997.

[28] G. Taguchi, Introduction to quality engineering: Design quality into products and process, Asian Productivity Organization, Tokyo, Japan, 1986.

[29] M.S. Phadke, Quality engineering using robust design, Prentice-Hall, Englewood Cliffs, NJ, 1989. 
ELK

Asia Pacific Journals
ELK Asia Pacific Journals - Special Issue

ISBN: 978-81-930411-4-7

\section{Annexure 1 (Process Flow Diagram)}

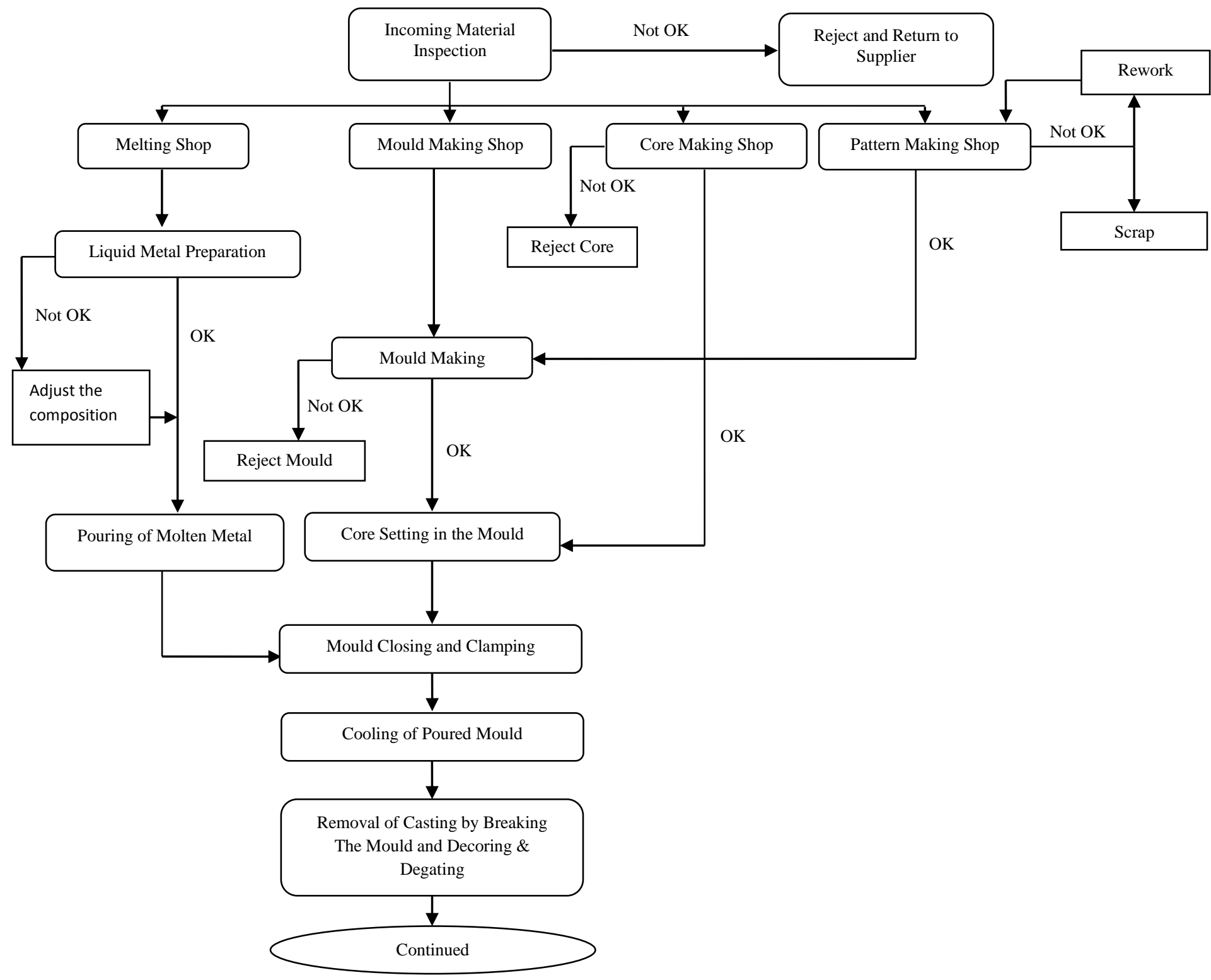


Asia Pacific Journals

ELK Asia Pacific Journals - Special Issue

ISBN: 978-81-930411-4-7

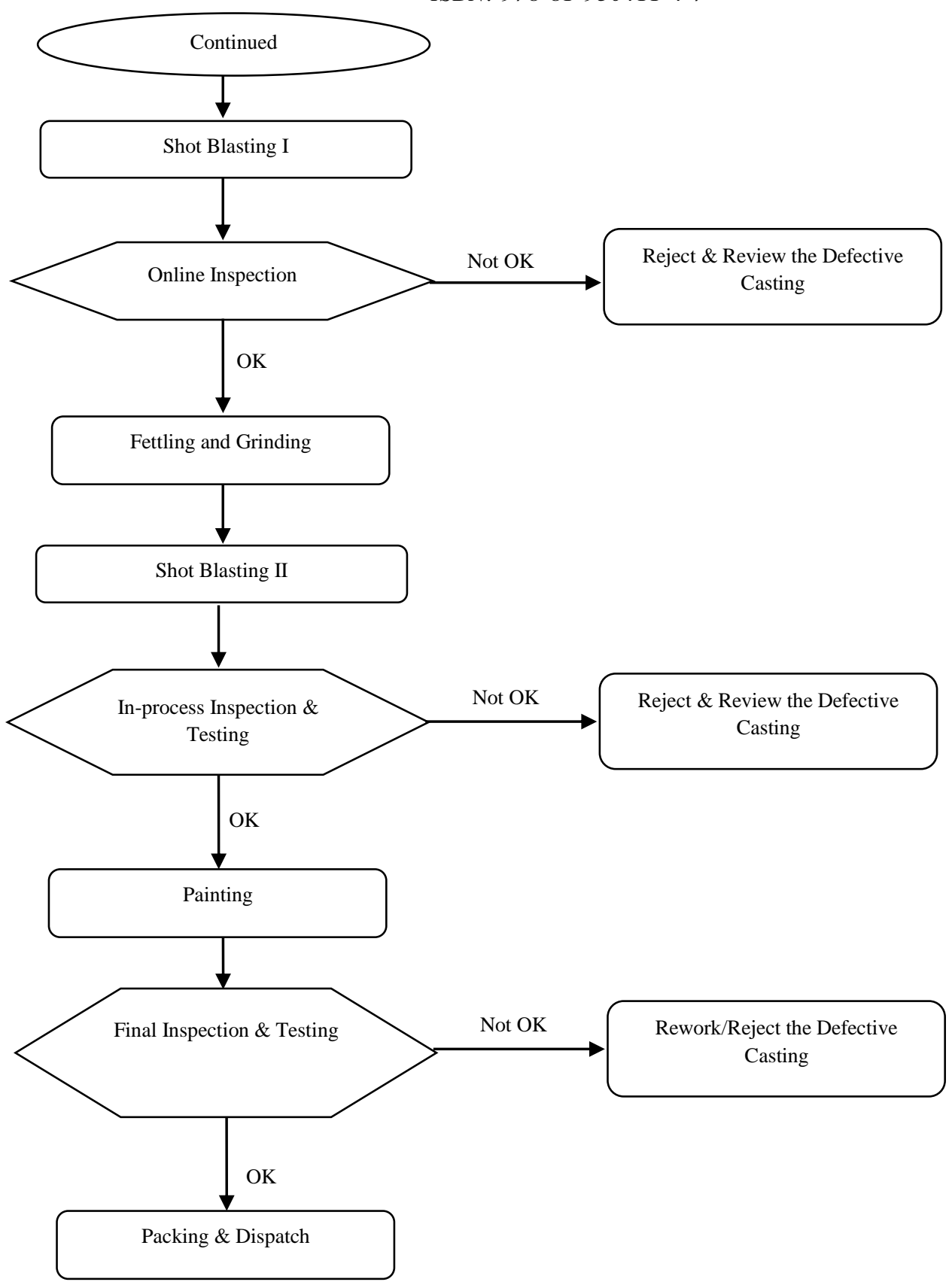

